University of Nebraska - Lincoln

DigitalCommons@University of Nebraska - Lincoln

Faculty Publications from the Harold W. Manter Laboratory of Parasitology

10-1977

\title{
Monoecocestus thomasi sp. n. (Cestoda: Anoplocephalidae) from the Northern Flying Squirrel, Glaucomys sabrinus (Shaw), in Oregon
}

\author{
Robert L. Rausch \\ University of Washington, rausch@uw.edu \\ C. Maser \\ University of Puget Sound
}

Follow this and additional works at: https://digitalcommons.unl.edu/parasitologyfacpubs

Part of the Parasitology Commons

Rausch, Robert L. and Maser, C., "Monoecocestus thomasi sp. n. (Cestoda: Anoplocephalidae) from the Northern Flying Squirrel, Glaucomys sabrinus (Shaw), in Oregon" (1977). Faculty Publications from the Harold W. Manter Laboratory of Parasitology. 365.

https://digitalcommons.unl.edu/parasitologyfacpubs/365

This Article is brought to you for free and open access by the Parasitology, Harold W. Manter Laboratory of at DigitalCommons@University of Nebraska - Lincoln. It has been accepted for inclusion in Faculty Publications from the Harold W. Manter Laboratory of Parasitology by an authorized administrator of DigitalCommons@University of Nebraska - Lincoln. 


\title{
MONOECOCESTUS THOMASI SP. N. (CESTODA: ANOPLOCEPHALIDAE) FROM THE NORTHERN FLYING SQUIRREL, GLAUCOMYS SABRINUS (SHAW), IN OREGON
}

\author{
R. L. Rausch* and C. Masert
}

\begin{abstract}
Monoecocestus thomasi sp. n. (Cestoda: Anoplocephalidae), from the northern flying squirrel, Glaucomys sabrinus (Shaw), in Oregon, is described and distinguished from its congeners. Monoecocestus thomasi is the sixth species of Monoecocestus to be described from nearctic rodents, and the first from a member of the family Sciuridae. Our comparisons of taxonomic characters of the nominal species of Monoecocestus in North American rodents have shown that M. giganticus Buhler 1970 is a synonym of $M$. americanus (Stiles 1895), both from the porcupine, Erethizon dorsatum (Linnaeus). Insemination in Monoecocestus spp. is discussed, with the conclusion that it takes place only by way of the vagina in early immature segments.
\end{abstract}

Helminths obtained from northern flying squirrels, Glaucomys sabrinus (Shaw), collected by one of us (C. M.) in Oregon, included cestodes of three species. The most common of these, found in G. sabrinus bangsi (Rhoads) in the Blue and Wallowa Mountains, represents an undescribed species of Monoecocestus Beddard 1914. This is the sixth species of Monoecocestus from Nearctic mammals and the first to be recorded from a rodent of the family Sciuridae. In this paper also, the taxonomic status of $M$. giganticus Buhler 1970 is considered, and insemination in cestodes of the genus Monoecocestus is discussed.

\section{MATERIALS AND METHODS}

The species described herein was represented by 27 specimens. After removal from the host, the cestodes were relaxed in water and fixed by immersion in a hot solution of $10 \%$ formalin. The following description was based on nine strobilae stained in acetic carmine or acid hematoxylin, processed by standard methods, and mounted permanently. The tegument and underlying layers of muscle fibers were removed from the anterior portions of selected strobilae for study of the internal organs, and transverse sections were cut at different levels of two strobilae. Eggs measured were obtained from gravid segments preserved in

Received for publication 21 December 1976.

* Department of Veterinary Microbiology, Western College of Veterinary Medicine, University of Saskatchewan, Saskatoon, Sask., Canada S7N oW0.

$\dagger$ Puget Sound Museum of Natural History, University of Puget Sound, Tacoma, Washington 98416. Present address: Pacific Northwest Forest and Range Experiment Station, Range and Wildlife Habitat Laboratory, Box 2315, LaGrande, Oregon 97850.
$10 \%$ formalin, and stained in an aqueous solution of Rose Bengal. Unless otherwise stated, all measurements are in micrometers.

\section{Monoecocestus thomasi sp. n. \\ (Figs. 1-5)}

Description: Strobila 72 to $137 \mathrm{~mm}$ long, with 119 to 161 segments (avg. 136); maximum width 4 to $5 \mathrm{~mm}$, attained in post-mature segments. Strobila thick and muscular, widening abruptly anteriorly, with slightly serrate margins. All segments wider than long, with length/width ratio increasing posteriad. Length/width ratio of mature segments 1:5 to 1:6; of terminal gravid segments about $1: 2$. Relatively small scolex 510 to 570 wide (avg. 531), not wider than first segments. Suckers 200 to 220 in greater diameter. Neck short or lacking. Genital pores regularly alternating (rarely unilateral in two successive segments), situated just anterior to middle of segmental margin in mature segments; slightly posterior to middle in gravid segments. Genital ducts passing dorsally across longitudinal excretory canals. Ventral canals 30 to 128 in diameter, connected across posterior margin of segment by transverse canal 48 to 98 in diameter; dorsal canals 25 to 64 in diameter, lateral to ventral canals. Anlagen of ovary and cirrus sac visible in first immature segments. Genital pore not patent in early immature segments; appearance of external opening coincident with insemination. Genital atrium 240 to 300 deep and 90 to 200 in diameter; in mature and postmature segments, partially or entirely obliterated by protrusion of cirrus sac laterad. Cirrus sac thick-walled, fully developed in late mature segments, extending slightly anteromediad and usually overlapping dorsal excretory canal; 520 to 630 long by 180 to 230 in maximum diameter in late mature segments (avg. 585 by 218 ), and attaining length of about 700 in post-mature segments. Maximum diameter of cirrus sac corresponding to position of internal seminal vesicle. Internal seminal vesicle nearly globular in late mature segments, 110 to 170 long by 150 to 160 


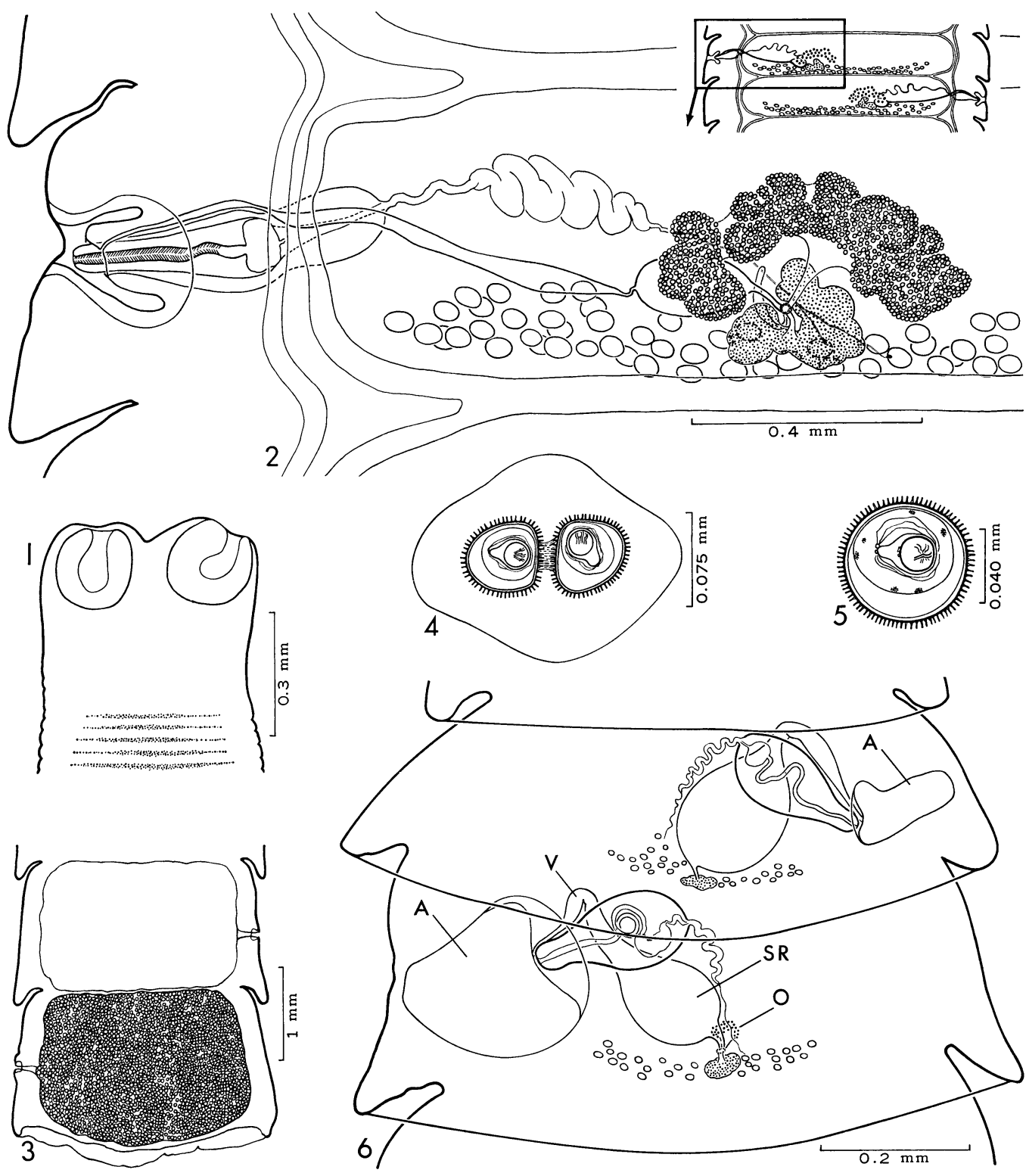

Figures 1-5. Monoecocestus thomasi sp. n. 1. Scolex. 2. Details of genital organs in early mature segment, ventral view. Inset shows portion of segment portrayed. 3. Gravid segment. 4. Paired eggs, gravid segments. 5. Details of egg, terminal gravid segment.

Figure 6. Monoecocestus americanus. Dorsal view of 9 th and 10th segments of a strobila 5.8 $\mathrm{mm}$ long with 19 segments, showing changes in the genital atrium. The genital pore was patent in the next (11th) segment and insemination had occurred. Abbreviations: A-genital atrium; V-vagina; $\mathrm{SR}$-seminal receptacle; $\mathrm{O}$-primordium of ovary.

in diameter. Cirrus spinose (spines may be lost from extruded organ), 430 to 470 long when extended; base of cirrus inflated, 70 to 80 in diameter, and 32 to 41 in diameter at distal end. External seminal vesicle undeveloped in immature segments. In early mature segments, external seminal vesicle consisting of convoluted tube attaining diameter of 90 to 130 , extending mediad from proximal end of cirrus sac; maximum size attained in post-mature segments. Subspherical 
testes about 130 per segment, 53 to 73 in greater diameter (avg. 65) in late mature segments, uniformly distributed dorsally across segment near posterior margin, overlapping posterior margins of ovary and vitelline gland, and not reaching ventral longitudinal excretory canals. Vagina first visible in early immature segments as cord-like aggregation of cells extending mediad from genital atrium to primordium of seminal receptacle. At about 20th segment, vagina enlarging medial to proximal end of cirrus sac, attaining diameter of 20 to 40 , and with distinct lumen. Opening in genital atrium ventral to orifice of male duct, vagina extending anteromediad, paralleling anterior margin of cirrus sac, then posteromediad to seminal receptacle. Vagina functional at least as far posterior as 42 nd to 63 rd segment, thereafter persisting in mature and early gravid segments as thin-walled tube 20 to 50 in diameter. Seminal receptacle filled about at 40 th segment; ellipsoidal, 150 to 220 long by 90 to 180 (avg. 191 by 116 ), situated dorsal to poral end of ovary and usually reaching poral margin of vitelline gland. Seminal duct extending posteromediad from aporal end of seminal receptacle, joining ovarian duct near middle of vitelline gland. Ovary arched, with large posterior concavity, situated ventrally with aporal margin near midline of mature segment; 576 to 640 wide by 240 to 320 long (avg. 589 by 276) in late mature segments; attaining size of about 816 by 480 in post-mature segments. Vitelline gland usually reniform, slightly lobed, 224 to 320 wide by 176 to 224 long (avg. 272 by 194) in mature segments, situated ventrally posterior to ovary and lying partly within posterior concavity of latter organ. Uterus arising dorsally, forming diffuse reticulum ventral in segment; gravid uterus filling entire segment between excretory canals. Cirrus sac, external seminal vesicle, and remnants of testes persisting in gravid segments, but usually obscured by eggs. Eggs spherical, 63 to 73 (avg. 67 ) in diameter, arranged in pairs within ellipsoidal matrix of clear substance. Outer membrane of egg covered by truncated spines about 3.5 long, 1 in diameter, spaced about 2 apart (usually not visible in permanently mounted specimens). Embryo 17 to 19 in greater diameter; embryonic hooks 9 to 10 long.

Type host: Northern flying squirrel, Glaucomys sabrinus bangsi (Rhoads).

Type locality: Approximately $25 \mathrm{~km}$ north of Lostine, Wallowa County, Oregon.

Habitat: Small intestine of host.

Types: Holotype, USNM Helm. Coll. No. 74380, collected on 11 May 1976; paratype, No. 74381, from flying squirrel collected at Powwatka Ridge, Wallowa County, Oregon, on 14 March 1976.

\section{Remarks}

This cestode is named for Dr. Jack Ward Thomas, U.S. Department of Agriculture Forest Service, Pacific Northwest Forest and
Range Experiment Station, LaGrande, Oregon, who has contributed significantly to the conservation of wildlife.

From one to six specimens (average three) of $M$. thomasi were found in nine of 11 flying squirrels collected in the Blue and Wallowa Mountains. The two not infected by $M$. thomasi harbored the anoplocephaline cestode Aprostatandrya sciuri (Rausch 1947), hitherto known only from the type material from the northern flying squirrel in Wisconsin. A hymenolepidid cestode, to be considered elsewhere, was found in three of four specimens of G. sabrinus oregonensis (Bachman) collected in the Coast Range of Oregon.

\section{DISCUSSION}

Taxonomic revisions of cestodes now included in the genus Monoecocestus Beddard 1914 have led in some cases to rather complex synonymies. The genus Monoecocestus was erected for cestodes described as $M$. erethizontis Beddard 1914, from a North American porcupine, Erethizon dorsatum (Linnaeus), that had died in the collection of the Zoological Society of London (Beddard, 1914). Baer (1925) studied two of Beddard's specimens and determined that Monoecocestus Beddard 1914 was a synonym of Schizotaenia von Janicki 1905. He found also that the two specimens represented both species of Schizotaenia then known from the porcupine, S. americana (Stiles 1895) and S. variabilis Douthitt 1915, and on the assumption that Beddard's description was a composite, he placed S. variabilis in synonymy with S. erethizontis. Although Baer remarked (1925, p. 1) that the material studied consisted of Beddard's "types and co-types," he did not establish that the specimen of S. variabilis was part of the series on which Beddard's description of $S$. erethizontis had been based. Beddard (1914, p. 1051) had recognized that the cestode described by him was morphologically similar to S. americana, and Chandler (1936) concluded that the description of $S$. erethizontis had been based exclusively on specimens of the former, ". . . whether or not there were others mixed with them." Chandler placed S. erethizontis in synonymy with $S$. americana, thereby restoring $S$. variabilis to designate the second species of Schizotaenia from the porcu- 
pine. Baer's taxonomic concept was accepted by Rego (1961), and that of Chandler by Freeman (1949) and Spasskii (1951). Yamaguti (1959, p. 382) listed erethizontis as a third independent species in porcupines. In agreement with Chandler (1936), we find no evidence that Beddard's description of S. erethizontis includes any of the morphologic characters of S. variabilis.

The species selected as type of the genus Schizotaenia was Taenia decrescens Diesing 1856, from peccaries, Dicotyles albirostris and D. torquatus [= Tayassu albirostris (Illiger) and T. tajacu (Linnaeus) (cf. Cabrera, 1961, p. 316) ], collected by Johannes Natterer in Brasil. Lühe (1895) studied one of Diesing's specimens in the collection of the Hof-Museum in Vienna, but the redescription that he provided is inadequate to permit certain generic allocation of the cestode from peccaries. Nonetheless, Baer (1927, p. 112) concluded that S. hagmanni von Janicki 1904, a parasite of the capybara, Hydrochoerus hydrochaeris (Linnaeus), in Brasil is conspecific with $S$. decrescens. Hughes $(1941$, p. 23 ) noted that T. decrescens Diesing 1856 is a homonym of T. decrescens Rudolphi in Creplin, 1849, and therefore unavailable. He proposed a new name, Schizotaenia diesingi Hughes 1941, for this taxon, although Baer's earlier action had made available the name $S$. hagmanni von Janicki 1904 for the species described by Diesing. In the meantime, Fuhrmann (1932, p. 427) had rejected the generic name Schizotaenia von Janicki 1904 on grounds of homonymy, replacing it with Monoecocestus Beddard 1914, the oldest available synonym. Contrary to the earlier conclusion by Baer (1927), Spasskii (1951, p. 427) considered $M$. decrescens to be distinct from $M$. hagmanni, but he retained the former in the genus Monoecocestus. Numerous cestodes from peccaries in Brasil have been studied by Rego (1961), but none represented the genus Monoecocestus. On these grounds, Rego (p. 333) suggested that "Tayassus (Dicotyles) albirostris seja eliminado da relação de hospedeiros de Monoecocestus." If $M$. decrescens is excluded, all but one of the 13 species of Monoecocestus now recognized are parasites of mammals of the order Rodentia. The exception is M. rheiphilus Voge and Read 1953, from a rheiform bird, Pterocnemia pennata (d'Orbigny), in Peru.

The records indicate that host-specificity is strongly defined in cestodes of the genus Monoecocestus. Each of the nominal species appears to occur in hosts of a single genus and most are known from a single species. However, as many as three species of Monoecocestus have been described from one hostspecies (capybara and porcupine), suggesting that the number of taxa might be reduced when sufficient material can be studied. On grounds of host-specificity and zoogeography, nearctic species of Monoecocestus would not be expected to occur in subtropical and tropical regions, and since comparisons with the descriptions of taxa reported from Central and South America and Cuba have shown that $M$. thomasi sp. n. is morphologically distinct, the eight species of Monoecocestus known from these regions are not considered further in the present paper.

\section{Comparisons}

Five species of Monoecocestus have been described from nearctic rodents, viz., $M$. americanus (Stiles 1895), M. variabilis (Douthitt 1915), M. anoplocephaloides (Douthitt 1915), M. sigmodontis (Chandler and Suttles 1922), and $M$. giganticus Buhler 1970.

Compared with $M$. americanus, the strobila of $M$. thomasi sp. n. is of similar proportions but much smaller. The aporal margin of the ovary extends approximately to the midline of the segment, whereas the ovary in M. americanus extends beyond the midline by about half its width, broadly overlapping the ovary in adjacent segments (cf. Stiles, 1896, pl. X, fig. 7; Freeman, 1952, fig. 1). The seminal receptacle is ellipsoidal and situated over the poral margin of the ovary, while that in $M$. americanus is spherical and lies within the posterior concavity of the ovary, just anterior to the poral margin of the vitelline gland. The eggs are larger, with an average diameter of 67 as compared with 61 in M. americanus. As observed by Buhler (1970) in M. giganticus, the eggs of $M$. americanus are arranged in pairs. Monoecocestus thomasi is distinguished further by differences in the dimensions and relationships of the various organs.

Monoecocestus thomasi has a much nar- 
rower strobila compared with that of $M$. variabilis, which in our material (see below) attained a maximum width of $13.5 \mathrm{~mm}$. The aporal margin of the ovary is near the midline of the segment, whereas the ovary of $M$. variabilis is situated porally. The testes are distributed uniformly across the posterior margin of the segment, while those of $M$. variabilis are arranged with the majority poral to the midline (cf. Freeman, 1952, fig. 2). The egg is larger than that of $M$. variabilis, of which the average greater diameter was 60 in our material; the eggs of $M$. variabilis also are arranged in pairs. Monoecocestus thomasi is distinguished further by differences in dimensions and proportions of other organs.

The strobila of $M$. thomasi is long and relatively narrow compared with the short, somewhat wedge-shaped strobila of $M$. anoplocephaloides (material studied: one mounted specimen from "pocket gopher," Colorado). The number of segments ranged from 119 to 161 , as compared with a maximum of 80 reported for M. anoplocephaloides (cf. Douthitt, 1915 , p. 385 ). The ovary is proportionally much smaller and situated farther porally, while that organ in $M$. anoplocephaloides is relatively very large and nearly centrally located. The egg is much larger than that of $M$. anoplocephaloides, the diameter of which Douthitt (1915, p. 389) reported to be 30 to 40 ; in our specimen, the average diameter of undistorted eggs was 43.

The strobila of $M$. thomasi is larger and more muscular than that of $M$. sigmodontis (material studied: one mounted specimen from Sigmodon hispidus Say and Ord, Ruskin, Florida). Chandler and Suttles (1922) reported that the strobila of $M$. sigmodontis attains a length of $65 \mathrm{~mm}$, with a maximum of 90 segments; our specimen was $74 \mathrm{~mm}$ long, with 108 segments. The cirrus sac of $M$. thomasi is relatively smaller and its proximal end is widely separated from the poral margin of the ovary, whereas that of $M$. sigmodontis extends anteromediad along the poral margin of the much larger, more porally situated ovary. The vitelline gland is relatively small and reniform, while that of $M$. sigmodontis is large and round. The ovary and testes do not extend so far anteriad in the segment as do those of $M$. sigmodontis. The egg of $M$. sig- modontis is smaller, with diameter ranging from 47 to 53 (Chandler and Suttles, 1922).

With $M$. americanus and $M$. variabilis, $M$. giganticus is the third species of Monoecocestus described from the porcupine. Two paratypes of $M$. giganticus, USNM Helm. Coll. No. 63230, were kindly lent by Dr. J. Ralph Lichtenfels. These were compared directly with cestodes from porcupines collected as follows (numbers of specimens are given in parentheses): $M$. variabilis-St. Andrews, New Brunswick, H. J. Van Cleave Collection No. 3897 (3); Mile 52, Glenn Highway, southcentral Alaska, 13 V 1963 (4); Little Susitna River, south-central Alaska, 24 III 1957 (4). M. americanus-Anchorage, Alaska, 15 III 1950 (9); 2 miles east of Anchorage, 26 XI 1955 (27); Mile 22, Glenn Highway, $13 \mathrm{~V}$ 1963 (1); Little Susitna River, 24 III 1957 (3 and 2); 2 miles south of Summit Lake, Alaska Range, 23 VII 1964 (4); 1 mile north of Aggie Creek, Seward Peninsula, Alaska, 18 VII 1966 (1); and Saskatoon, Saskatchewan, 18 IX 1962 (leg. J. Pitchko) (2). Mixed infections of the two species were found in two porcupines in Alaska. Comparisons were made also with Freeman's (1949) detailed descriptions of these cestodes.

In differentiating $M$. giganticus, Buhler (1970) referred to the descriptions of $M$. americanus and $M$. variabilis in Spasskii (1951), taken from the monograph by Baer (1927). Monoecocestus giganticus was distinguished from its congeners in porcupines mainly on the basis of size of strobila, number and distribution of testes, and lack of a functional vagina. The five cestodes studied by Buhler ranged from 139 to $203 \mathrm{~mm}$ in length, as compared with lengths of 20 and $33 \mathrm{~mm}$ for $M$. erethizontis ( $=M$. variabilis) and $M$. americanus, respectively, according to Baer (1927). Freeman (1949) reported that the latter attained lengths of 174 and $270 \mathrm{~mm}$, respectively. In our material, maximum lengths were $68 \mathrm{~mm}$ for $M$. variabilis and 215 $\mathrm{mm}$ for $M$. americanus. Concerning the testes in $M$. giganticus, Buhler (p. 243) observed "Twenty to $40 \ldots, 90-130$ in diameter, arranged in posterior lateral fields, separated by ovary, extending to osmoregulatory canals." In the paratypes, however, we found that the testes extended dorsally uninterruptedly across 
the ovary and that their distribution was like that in $M$. americanus. We were unable to make an exact count of the testes, but found that the number exceeded the reported maximum of 40. Freeman (1949) reported a range of 50 to 103 testes per segment in M. americanus.

Concerning $M$. giganticus, Buhler stated ( $\mathrm{p}$. 245) that "The vestigial vagina in immature proglottids does not open to the outside at any time. ...," and he concluded that fertilization occurred by means of hypodermic impregnation. As was described by Freeman in $M$. americanus, we found in the paratypes of $M$. giganticus that the vagina opened into the genital atrium in immature segments, that a genital pore was present, and that the vagina could be traced from the atrium to the seminal receptacle. Moreover, at least portions of the vagina were visible in mature segments. After tracing the formation of the genital atrium and associated structures, we conclude that the vagina is functional, and that the process of insemination in Monoecocestus spp. does not differ fundamentally from that in other anoplocephaline cestodes. The pattern of development of the genital atrium was identical in the species of Monoecocestus studied by us. In early immature segments, in which the component structures of the cirrus sac had not yet differentiated, the genital atrium was first visible as a minute cavity at the poral end of the cirrus sac, medial to the segmental margin. Posteriad, the anteroposterior diameter of the cavity increased progressively, and at the same time the poral wall of the atrium approached the segmental margin. By the time the cirrus sac contained a fully developed cirrus and the vagina could be traced from the still empty seminal receptacle to its opening in the atrial fundus anterior to the orifice of the male duct, the genital atrium had attained near-maximum size and its lumen was covered laterally by only a thin layer of tissue (cf. Fig. 6), which was frequently found to bulge outward over the atrial lumen. Immediately thereafter, in the following segment, the external opening appeared, and insemination occurred, as indicated by the distension of the seminal receptacle by spermatozoa in such segments. Douthitt (1915, p. 386) discussed the formation of the atrium in $M$. anoplo- cephaloides, although he did not relate his observations to insemination.

As did Buhler (1970, fig. 4), we found in one of the paratypes of $M$. giganticus that the cirrus in mature segments had perforated the posterior wall of the genital atrium, but we consider this to be an anomalous condition unrelated to the process of insemination. Freeman (1949, p. 608) reported that a functional vagina was usually present in $M$. americanus in the 5th to the 10th segment posterior to the scolex, but he did not indicate the size (length of strobila) of specimens on which this observation was made. In the largest of our specimens of M. americanus (strobilae ca. $200 \mathrm{~mm}$ long), the initial cavity of the genital atrium was first visible in the 18th or 19th segment, and opening of the genital pore with insemination occurred in the 30th to 33rd segment. In the paratypes of $M$. giganticus, insemination had occurred in the 28th and 29th segments, respectively. However, the genital atrium and associated structures developed more rapidly in small strobilae of $M$. americanus. In the intestine of a porcupine collected near Anchorage, on 26 November 1955, 1165 specimens of this cestode were found, with individuals ranging in length from 4 to about $45 \mathrm{~mm}$. Fully developed eggs were present in a strobila only $25 \mathrm{~mm}$ long, with 56 segments. In smaller strobilae, none of which contained mature segments, the genital pore was patent and the seminal receptacle filled in the 6th to 13th segment posterior to the scolex. A specimen $5.8 \mathrm{~mm}$ long, with only 19 segments, had a patent genital pore in the 11th segment and insemination had occurred (cf. Fig. 6). In the other nearctic species of Monoecocestus, patency of the genital pore and a filled seminal receptacle were noted as follows: M. variabilis, 13th to 24th segment; M. thomasi, 33rd to 46th segment; $M$. sigmodontis (one specimen), 56th segment; $M$. anoplocephaloides (one specimen), 21st segment.

Concerning at least the nearctic species of Monoecocestus, we conclude that insemination takes place only by way of the vagina in segments in which neither the male reproductive organs nor the ovary are yet functional. The sequence of development of the genital organs indicates that self-fertilization 
does not occur in individual segments, and would seem to favor cross-fertilization between strobilae. However, in specimens of $M$. sigmodontis and $M$. thomasi (one each) that occurred singly in the host, the filled seminal receptacles indicated insemination by mature segments of the same strobila. Since no increase in the size of the seminal receptacle after its initial filling by spermatozoa was noted in any of the cestodes studied, it appears that a single copulation may serve to inseminate each segment. An entire mounted specimen of $M$. americanus demonstrating the morphologic characteristics described above has been deposited in the USNM Helm. Coll. No. 74382.

On the basis of these findings, we conclude that $M$. giganticus does not differ from $M$. americanus in any characters considered to have taxonomic significance, and that $M$. giganticus Buhler 1970 is thus a synonym of M. americanus (Stiles 1895).

\section{ACKNOWLEDGMENTS}

Mr. R. Anderson, U.S. Department of Agriculture Forest Service, Wallowa, assisted in the collection of flying squirrels in Oregon. Comparative material was made available by Dr. J. R. Lichtenfels, Animal Parasite Institute, Agricultural Research Center, Beltsville, and by Dr. G. D. Schmidt, Department of Biological Sciences, University of Northern Colorado, Greeley. Professor H. W. Stunkard, Department of Living Invertebrates, American Museum of Natural History, New York, made helpful comments concerning synonymies in Monoecocestus. Mrs. V. R. Rausch, Department of Veterinary Microbiology, University of Saskatchewan, prepared the figures. We express our thanks for these contributions.

\section{LITERATURE CITED}

BAer, J. G. 1925. Some Cestoda described by Beddard, 1911-1920. Ann Trop Med Parasitol 19: $1-22$
1927. Monographie des cestodes de la famille des Anoplocephalidae. Bull Biol Fr Belg, suppl 10, 241 p.

Beddard, F. E. 1914. Contributions to the anatomy and systematic arrangement of the Cestoidea. XV. On a new genus and species of the family Acoleidae. Proc Zool Soc London 4: 1039-1055.

BUHLER, G. A. 1970. Monoecocestus giganticus sp. n. (Cestoda: Anoplocephalidae) from the porcupine Erethizon dorsatum L. (Rodentia). Proc Helminthol Soc Wash 37: 243-245.

Cabrera, A. 1961. Catalogo de los mamiferos de America del Sur. Vol. II. Rev Mus Argent Cienc Nat "Bernardino Rivadavia" Inst Nac Invest Cienc Nat 4: 1-732.

Chandler, A. C. 1936. The genus Schizotaenia in porcupines. J Parasitol 22: 513.

— AND C. L. Sutrles. 1922. A new rat tapeworm, Schizotaenia sigmodontis, from North America. J Parasitol 8: 123-128.

Douthiт, $H$. 1915. Studies on the cestode family Anoplocephalidae. Illinois Biol Monogr 1: $353-446$.

Freeman, R. S. 1949. Notes on the morphology and life cycle of the genus Monoecocestus Beddard, 1914 (Cestoda: Anoplocephalidae) from the porcupine. J Parasitol 35: 605612.

- 1952. The biology and life history of Monoecocestus Beddard, 1914 (Cestoda: Anoplocephalidae) from the porcupine. J Parasitol 38 : 111-129.

FuhrmanN, O. 1932. Les ténias des oiseaux. Mem Univ Neuchâtel 8: 1-381.

Hughes, R. C. 1941. The Taeniae of yesterday. Bull Oklahoma Agri Mech Coll 38: 1-83.

LüHE, M. 1895. Mitteilungen über einige wenig bekannte bez. neue südamerikanische Taenien des k. k. naturhistorischen Hof-Museums in Wien. Arch Naturgesch 61: 199-212.

Rego, A. A. 1961. Revisão do gênero Monoecocestus Beddard, 1914 (Cestoda, Anoplocephalidae). Mem Inst Oswaldo Cruz 59: 325-354.

Spassku, A. A. 1951. Anoplotsefaliaty-lentochnye gel'minty domashnikh i dikikh zhivotnykh. Osnovy tsestodologii, Vol. I. Akad Nauk SSSR, Moskva, 735 p.

Stiles, C. W. 1896. A revision of the adult tapeworms of hares and rabbits. Proc U S Nat Mus 19: 145-235.

Yamaguti, S. 1959. Systema helminthum. Vol. II. The Cestodes of Vertebrates. Interscience Publishers, New York, 860 p. 